\title{
Evaluasi CSE-UCLA pada Studi Proses Pembelajaran Matematika
}

\author{
Siska Andriani \\ IAIN Raden Intan Lampung: mathicmath@yahoo.co.id
}

Submitted : 10-09-2015, Revised : 23-11-2015, Accepted : 16-12-2015

\begin{abstract}
Standards process are one of the national standards governing the planning, implementation, assessment, and supervision of the learning process. Implementation of process standards that occurred in the field has not seen its implementation. The purpose of this study is to obtain a description of the implementation of process standards in the process of learning mathematics using CSE-UCLA analysis at SMP Negeri Satu Atap Lerep. This research is a qualitative research with evaluative approach. The main data source is the math teacher. Techniques of collecting data using interviews, observation, and documentation. The validity of data used in this study used the credibility test (triangulation and adequacy of reference materials), transferability test, and dependability test. The results showed that the process of learning mathematics at SMP Negeri Satu Atap Lerep has followed the standard process. Implementation of process standards with CSE-UCLA analysis shows that process standards are implemented through the planning, development, implementation, impact and impact phases. The impact that arises from learning that occurs is not maximal. In addition, many factors influence the implementation of process standards in mathematics learning at SMP Negeri Satu Atap Lepep. These factors are supporting and inhibiting factors.
\end{abstract}

Keywords: CSE-UCLA; Learning; Process; Standard.

\begin{abstract}
Abstrak
Standar proses merupakan salah satu standar nasional yang mengatur perencanaan, pelaksanaan, penilaian, dan pengawasan proses pembelajaran. Pelaksanaan standar proses yang terjadi di lapangan belum terlihat keterlaksanaannya. Tujuan penelitian ini yaitu memperoleh deskripsi keterlaksanaan standar proses pada proses pembelajaran matematika menggunakan analisis CSE-UCLA di SMP Negeri Satu Atap Lerep. Penelitian ini merupakan penelitian kualitatif dengan pendekatan evaluatif. Sumber data utama adalah guru matematika. Teknik pengumpulan data menggunakan wawancara, observasi, dan dokumentasi. Keabsahan data yang digunakan dalam penelitian ini menggunakan uji credibility (triangulasi dan kecukupan bahan referensi), uji transferability, dan uji dependability. Hasil penelitian menunjukkan bahwa proses pembelajaran matematika di SMP Negeri Satu Atap Lerep sudah mengikuti standar proses. Implementasi standar proses dengan analisis CSE-UCLA menunjukkan bahwa standar proses dilaksanakan melalui tahap perencanaan, pengembangan, implementasi, hasil dan dampak. Dampak yang muncul pembelajaran yang terjadi tidak maksimal. Selain itu, banyak faktor yang mempengaruhi implementasi standar proses pada pembelajaran matematika di SMP Negeri Satu Atap Lerep. Faktor-faktor tersebut berupa faktor pendukung dan faktor penghambat.
\end{abstract}

Kata Kunci : CSE-UCLA; Pembelajaran; Standar; Proses. 


\section{PENDAHULUAN}

Mutu pendidikan Indonesia di mata dunia makin memprihatinkan. Peringkat Indonesia dalam HDI (Human Development Index) pada tahun 2011 dari peringkat ke 111 dari 182 negara ke peringkat 124 dari 187 negara. HDI mengukur peringkat suatu negara dalam bidang pendidikan, kesehatan dan kesejahteraan ekonomi. Menurunnya peringkat Indonesia tersebut khususnya dalam bidang pendidikan menjadi salah satu faktor yang menyebabkan sekolah-sekolah Indonesia belum dapat bersaing dalam tataran global. Selain itu berdasarkan hasil penelitian PISA (Programme for International Student Assessment) Indonesia untuk mata pelajaran matematika pada tahun 2009 berada di urutan 61 dari 65 negara yang berpartisipasi dengan nilai rata-ratanya 371 dibawah dari nilai rata-rata standar 500 (Tim PISA Indonesia, 2011).

Matematika merupakan salah satu ilmu yang diperlukan dalam kehidupan manusia, karena melalui pembelajaran matematika peserta didik dilatih agar dapat berpikir kritis, logis, sistematis, dan dapat menyelesaikan masalah yang dihadapinya dalam kehidupan sehari-hari. Berdasarkan pernyataan tersebut matematika menjadi penting untuk dipelajari dan diterapkan dalam proses pembelajaran dari jenjang sekolah dasar hingga jenjang sekolah yang lebih tinggi.

Kurikulum merupakan bagian yang tak terpisahkan dari pembelajaran sehingga harus dipahami guru. Akinoglu (2008) menyatakan kurikulum pendidikan menyampaikan nilai-nilai substansial dan prioritas kelembagaan. Bharvad (2010) menyatakan kurikulum yang baik adalah kurikulum yang mementingkan perkembangan anak, sistem dan kepentingan nasional. Kurikulum tidak bermakna tanpa adanya kemampuan guru dalam mengimplementasikannya dalam proses pendidikan. Bulut (2007) menyatakan bahwa guru dapat mengaktifkan anak-anak untuk belajar dan memahami apa yang diajarkan dengan efektif jika guru memiliki strategi yang efektif. Penelitian Chapman (2012) menyatakan bahwa dukungan untuk implementasi kurikulum yang baru berasal dari dalam sekolah tempat mengajar. Representasi diri guru menjadi hal yang penting dalam proses pembelajaran, seperti yang diungkap oleh Chapman (2010) bahwa representasi diri adalah hal yang relevan dan penting dalam mengajar matematika dan pendidikan guru mengingat bahwa hal itu bisa menjadi produktif atau tidak produktif sebagai alat dalam memfasilitasi siswa belajar matematika.

Anthony (2009: 149) menyatakan pedagogi matematika yang efektif, yakni: (1) Mengakui bahwa semua peserta didik, terlepas dari usia, dapat mengembangkan identitas matematika positif dan menjadi pembelajar matematika yang kuat; (2) Didasarkan pada penghormatan interpersonal dan sensitivitas dan responsif terhadap banyaknya warisan budaya, proses berpikir, dan realitas yang ditemukan di kelas sehari-hari; (3) Difokuskan pada optimalisasi berbagai hasil akademik yang diinginkan meliputi pemahaman konseptual, prosedural kelancaran, kompetensi strategis, dan penalaran adaptif; (4) Berkomitmen untuk meningkatkan berbagai hasil sosial dalam kelas matematika yang akan memberikan kontribusi bagi pengembangan holistik peserta didik untuk kewarganegaraan yang produktif.

Pembelajaran merupakan salah satu bentuk program, karena pembelajaran yang baik memerlukan perencanaan yang matang dan dalam pelaksanaannya melibatkan guru dan peserta didik. Program pembelajaran yang dibuat oleh guru perlu diadakan evaluasi. 
Menurut Suchman (Arikunto dan Cepi, 2010) evaluasi merupakan proses menentukan hasil yang telah dicapai beberapa kegiatan yang direncanakan untuk mendukung tercapainya tujuan. Hal ini berarti evaluasi merupakan suatu proses atau kegiatan pemilihan, pengumpulan, analisis dan penyajian informasi yang dapat digunakan sebagai dasar pengambilan keputusan serta penyusunan program selanjutnya. Evaluasi program pendidikan memiliki banyak model yang dapat digunakan salah satunya model CSE-UCLA ( Center for the Study of Evaluation - University of California in Los Angeles). CSE-UCLA merupakan salah satu model atau desain yang digunakan dalam mengevaluasi suatu program pendidikan. Model CSE-UCLA merupakan model yang dikembangkan oleh Alkin (1969). Ciri dari model CSE-UCLA adanya lima tahap yang dilakukan dalam evaluasi yaitu perencanaan, pengembangan, implementasi, hasil dan dampak. Nyre dan Rose (1979) menyatakan keuntungan dari model CSE adalah bahwa hal ini berlaku untuk evaluasi diskrit, program instruksional yang didefinisikan dan sistem pendidikan dalam skala luas.

Keberhasilan implementasi suatu strategi pembelajaran akan tergantung pada kepiawaian guru dalam mengunakan metode, teknik dan taktik pembelajaran, sehingga guru juga berperan sebagai pengelola pembelajaran (manager of learning). Guru sebagai tempat bertanya, teman diskusi dan mencurahkan seluruh pengetahuan dan gagasan serta kompetensi peserta didik sehingga tidak canggung.

Penelitian ini menggunakan pendekatan evaluatif, yaitu evaluasi terhadap proses pembelajaran dilakukan dengan membandingkan antara standar ideal pada proses pembelajaran dengan kondisi nyata di lapangan. Fungsi penelitian dengan pendekatan evaluatif selain untuk mengetahui keberhasilan atau kegagalan program dan mengetahui penyebabnya, dimungkinkan penyempurnaan kinerja program di masa mendatang dan menghindari kesalahan yang telah dibuat pada masa lalu.

Permasalahan yang muncul dalam penelitian ini yaitu (1) bagaimanakah implementasi standar proses dalam pembelajaran matematika di SMP Negeri Satu Atap Lerep? (2) bagaimanakah proses pembelajaran matematika di SMP Negeri Satu Atap Lerep dianalisis dengan model evaluasi CSE-UCLA? (3)apakah faktor pendukung dan penghambat dalam mencapai standar proses yang ideal pada pembelajaran matematika di SMP Negeri Satu Atap Lerep?. Tujuan penelitian ini memperoleh deskripsi tentang pencapaian standar proses pembelajaran matematika, memperoleh deskripsi tentang proses pembelajaran matematika yang dianalisis dengan model evaluasi CSE-UCLA, mengetahui faktor pendukung dan penghambat dalam pencapaian standar proses pembelajaran matematika.

\section{METODE PENELITIAN}

Penelitian ini menggunakan pendekatan kualitatif yang bersifat evaluatif dengan sumber data menggunakan lingkungan SMP Negeri Satu Atap Lerep. Penelitian bersifat evaluatif karena membandingkan proses pembelajaran yang ada di lapangan dengan standar proses yang ideal. Evaluasi proses pembelajaran menggunakan model evaluasi CSE UCLA (Center for the Study of Evaluation - University of California in Los Angeles).

Data yang diperoleh meliputi hasil pengamatan, hasil wawancara, hasil dokumentasi, analisis dokumen tidak dituangkan dalam angka-angka namun dinyatakan dalam bentuk kata-kata dan gambar. Peneliti mencari informasi selengkap mungkin mengenai implementasi standar proses yang meliputi perencanaan proses pembelajaran matematika, 
pelaksanaan proses pembelajaran matematika, penilaian hasil pembelajaran matematika dan pengawasan proses pembelajaran matematika di SMP Negeri Satu Atap Lerep. Subjek yang akan diteliti dalam penelitian ini yaitu kepala sekolah, wakil kepala sekolah, guru matematika, dan peserta didik. Guru matematika SMP Negeri Satu Atap Lerep sebagai sumber data primer dalam penelitian ini. Sumber data sekunder yaitu kepala sekolah, wakil kepala sekolah bidang kurikulum, peserta didik di SMP Negeri Satu Atap Lerep. Instrumen yang digunakan adalah pedoman wawancara, pedoman observasi dan dokumentasi. Teknik pengumpulan data yang digunakan dalam penelitian ini adalah dokumentasi, observasi, dan wawancara. Teknik pemeriksaan keabsahan data yang dilakukan dalam penelitian ini meliputi yakni uji credibility, uji transferability, uji dependability, dan uji confirmability.

Peneliti menggunakan ketiga metode dalam mencari informasi kepada guru matematika dan kepala sekolah agar data yang didapatkan merupakan data yang sesuai dengan kenyataan. Peneliti menggunakan triangulasi sumber data untuk mendapatkan keabsahan data mengenai proses pembelajaran matematika dengan menanyakan hal yang sama kepada narasumber yang berbeda.

Peneliti menggunakan uji credibility dengan triangulasi dan bahan referensi. Triangulasi dilakukan untuk menghilangkan perbedaan-perbedaan konstruksi dan penelitian yang didapatkan, melalui triangulasi peneliti telah melakukan pengecekan data temuan yaitu membandingkan dengan berbagai sumber data dan metode. Cara ini baik untuk mengurangi bias yang melekat pada suatu metode dan memudahkan melihat keluasan penjelasan yang dikemukakan. Triangulasi yang digunakan dalam penelitian ini yaitu triangulasi sumber dan triangulasi metode. Peneliti menggunakan triangulasi metode yaitu wawancara, observasi dan dokumentasi dalam mencari keabsahan data mengenai proses pembelajaran matematika di SMP Negeri Satu Atap Lerep. Uji transferability mengenai proses pembelajaran matematika dilakukan peneliti dengan memberikan uraian rinci, sistematis, jelas, dan dapat dipercaya dalam membuat laporan penelitian hasil perolehan data pada proses pembelajaran matematika di SMP Negeri Satu Atap Lerep. Uji dependability dilakukan dengan melakukan audit kebergantungan terhadap keseluruhan proses penelitian yang telah dilakukan peneliti. Uji confirmability merupakan pengujian hasil penelitian yang dikaitkan pada proses penelitian yang dilakukan peneliti. Bila hasil penelitian merupakan fungsi proses penelitian, maka penelitian ini memenuhi uji confirmability Uji confirmability mirip dengan uji dependability, sehingga pengujian confirmability dilakukan bersamaan dengan uji dependability.

Evaluasi model CSE-UCLA digunakan untuk memilah-milah data yang terkumpul berdasarkan kategori perencanaan, pengembangan, implementasi, hasil dan dampak. Data yang didapatkan kemudian dianalisis dengan menggunakan teknik deskriptif kualitatif model Miles dan Huberman (Sugiyono,2010:337) yang terdiri dari tiga kegiatan, yaitu reduksi data, penyajian data, penarikan kesimpulan atau verifikasi.

\section{HASIL PENELITIAN DAN PEMBAHASAN}

Perencanaan proses pembelajaran diawali dengan kegiatan mengembangkan silabus dan RPP. Pengembangan silabus mata pelajaran matematika tidak dilakukan oleh guru secara mandiri. Guru menggunakan silabus yang diberikan oleh dinas pendidikan. Pengembangan silabus dapat dilakukan oleh para guru secara mandiri atau berkelompok 
dalam sebuah sekolah/madrasah atau beberapa sekolah, kelompok Musyawarah Guru Mata Pelajaran (MGMP) atau Pusat Kegiatan Guru (PKG), dan Dinas Pendidikan (BSNP, 2007). Guru matematika melakukan pemetaan, pemilahan, dan pengembangan terhadap sebagian standar kompetensi dan kompetensi dasar sebelum melakukan pengembangan silabus mata pelajaran matematika dalam forum MGMP. Guru matematika menggunakan kalender akademik yang berasal dari dinas pendidikan, pemuda dan olahraga sebagai dasar penyusunan program tahunan dan program semester.

Rencana pelaksanaan pembelajaran (RPP) matematika, di dalamnya tergambar sebuah perencanaan awal bagaimana proses pembelajaran di kelas yang di lakukan oleh guru meliputi interaksi guru dengan peserta didik dan peserta didik dengan peserta didik. RPP mata pelajaran matematika dikembangkan secara mandiri oleh guru. Pengembangan RPP mengacu pada silabus yang berikan dinas dan contoh RPP dari internet. Sebagaimana yang dijabarkan di dalam standar proses (BSNP, 2007), RPP disusun oleh guru pada satuan pendidikan. Setiap guru pada satuan pendidikan berkewajiban menyusun RPP secara lengkap dan sistematis agar pembelajaran berlangsung secara interaktif, inspiratif, menyenangkan, menantang, memotivasi peserta didik untuk berpartisipasi aktif. RPP dijabarkan dari silabus untuk mengarahkan kegiatan belajar peserta didik dalam upaya mencapai kompetensi dasar.

Langkah-langkah pengembangan dan penyusunan RPP matematika yang dilakukan guru sebagai berikut menuliskan identitas mata pelajaran, merumuskan tujuan pembelajaran, merumuskan materi pokok pembelajaran, memilih metode pembelajaran, merencanakan kegiatan pembelajaran, menentukan alat dan sumber belajar, menentukan prosedur penilaian untuk mengukur kemampuan dan hasil belajar peserta didik, dan menentukan alokasi waktu pembelajaran.

Persyaratan pelaksanaan proses pembelajaran meliputi rombongan belajar, beban kerja guru, dan buku teks pelajaran (BSNP, 2007). Jumlah peserta didik untuk kelas 7 melebihi batas maksimal untuk rombongan belajar tingkat SMP. Kelas 7 terdiri dari 2 rombongan belajar yang masing-masing terdiri dari 40 dan 41 peserta didik. Beban kerja guru yaitu 28 jam perminggu. Buku teks pelajaran matematika yang digunakan ditentukan melalui hasil rapat, dengan mempertimbangkan buku-buku yang ditetapkan oleh menteri. Guru berusaha menciptakan lingkungan belajar yang dapat merangsang peserta didik untuk belajar, memberikan rasa aman dan nyaman serta kepuasan dalam belajar. Tujuan pengelolaan kelas menurut Usman (2002) adalah mengembangkan kemampuan peserta didik dalam menggunakan alat-alat belajar, menyediakan kondisi-kondisi yang memungkinkan peserta didik bekerja dan belajar, serta membantu peserta didik untuk memperoleh hasil yang diharapkan.

Pelaksanaan pembelajaran merupakan implementasi dari rencana pelaksanaan pembelajaran. Guru dalam melaksanakan proses pembelajaran (Mulyasa, 2010) harus berupaya agar peserta didik dapat membentuk kompetensi dirinya sesuai dengan apa yang digariskan standar kompetensi dan kompetensi dasar sebagaimana dijabarkan dalam rencana pelaksanaan pembelajaran. Pelaksanaan pembelajaran mencakut tiga kegiatan, yakni pembukaan, inti, dan penutup. Kegiatan pembelajaran matematika yang dilakukan guru menunjukkan bahwa guru menguasai materi pembelajaran matematika, dan guru 
mampu mengkaikan materi dengan pengetahuan lain yang relevan selain itu guru memiliki memiliki kemampuan khusus pembelajaran matematika.

Penilaian dilakukan oleh guru terhadap hasil pembelajaran untuk mengukur tingkat pencapaian kompetensi peserta didik, serta digunakan sebagai bahan penyusunan laporan kemajuan hasil belajar, dan memperbaiki proses pembelajaran (BSNP, 2007). Melalui proses penilaian, akan diperoleh potret kemampuan peserta didik dalam mencapai standar kompetensi dan kompetensi dasar. Prosedur penilaian hasil belajar matematika yang dikembangkan oleh guru berupa teknik tes, teknik observasi dan penugasan perorangan maupun kelompok.

Pengawasan proses pembelajaran matematika dilakukan oleh kepala sekolah. Hal ini sesuai dengan apa yang diutarakan Sagala (2012), dalam konteks pembelajaran, pengawasan dilakukan oleh kepala sekolah terhadap seluruh kelas apakah terjadi kegiatan pembelajaran dan mengawasi pihak-pihak yang terkait dengan pembelajaran apakah dengan sungguh-sungguh memberikan pelayanan kebutuhan pembelajaran. Pengawasan proses pembelajaran matematika sesuai dengan standar proses. Pengawasan proses pembelajaran matematika meliputi pemantauan, supervisi, evaluasi, pelaporan dan tindak lanjut. Hasil pengawasan proses pembelajaran matematika digunakan untuk umpan balik kinerja pembelajaran matematika untuk ditindak lanjuti dengan mengacu pada standar proses. Setiap pihak yang menerima laporan hasil pengawasan proses pembelajaran matematika melakukan tindak lanjut laporan untuk meningkatkan mutu pembelajaran yang ada di SMP Negeri Satu atap Lerep, dan diberikan sangsi bila ditemukan penyimpangan dalam proses pembelajaran matematika.

Analisis CSE-UCLA pada proses pembelajaran di SMP Negeri Satu Atap Lerep untuk mengetahui keterlaksanaan pada perencanaan proses pembelajaran, pelaksanaan proses pembelajaran, penilaian hasil pembelajaran dan pengawasan proses pembelajaran dengan standar proses yang ideal. Perencanaan proses pembelajaran matematika meliputi pengembangan silabus dan rencana pelaksanaan pembelajaran (RPP). Silabus adalah ancangan pembelajaran yang berisi rencana bahan ajar mata pelajaran tertentu pada jenjang dan kelas tertentu, sebagai hasil dari seleksi, pengelompokan, pengurutan, dan penyajian materi kurikulum, yang dipertimbangkan berdasarkan ciri dan kebutuhan daerah setempat (Majid, 2008). Silabus tidak dikembangkan oleh guru baik secara mandiri maupun berkelompok. Silabus yang digunakan oleh sekolah merupakan silabus yang diberikan oleh Dinas Pendidikan. Hal ini mengakibatkan silabus tidak disesuaikan dengan kondisi sekolah maupun kondisi peserta didik.

Persyaratan pelaksanaan proses pembelajaran matematika tidak dapat dilaksanakan sesuai dengan standar proses dikarenakan keterbatasan yang ada di sekolah. Jumlah peserta didiknya melebihi jumlah standar. Dengan jumlah peserta didik yang melebihi standar, ada kalanya guru akan mengalami kendala dalam menunaikan kewajibanya sebagai guru. Seperti yang dinyatakan Syaifurahman (2013) kelas yang padat berpotensi kacau, peserta didik mulai sibuk dengan kegiatan masing-masing, bercerita, bercanda, dan dan bertingkah laku yang tidak sopan sehingga menghambat guru menunaikan kewajibannya.

Beban kerja guru pun menjadi syarat penting yang harus dipertimbangkan dalam pelaksanaan proses pembelajaran. Guru yang terlalu telah tidak akan optimal memberikan pelayanan kepada sekolah umumnya, dan peserta didik khususnya. Jika seseorang 
mempunyai banyak pekerjaan, akan sulit untuk menentukan mana yang harus dikerjakan terlebih dahulu (Sagala, 2012). Berdasarkan data dan temuan penelitian jumlah maksimal peserta didik setiap rombongan belajar, buku teks pelajaran matematika pun perlu dicermati dalam pelaksanaan pembelajaran matematika. Rasio buku teks pelajaran matematika yang di untuk peserta didik tidak memenuhi1-1.

Pengelolaan kelas yang dilakukan guru yang tidak sesuai dengan standar proses, yakni guru tidak mengatur tempat duduk sesuai dengan karakteristik peserta didik dan aktivitas pembelajaran yang akan dilakukan. Guru seharusnya memikirkan bagaimana cara mengorganisasikan ruang kelas, guru harus bertanya pada dirinya sendiri, tipe aktifitas apa yang akan diajarkan dan diterima oleh peserta didik, sehingga dapat mempertimbangkan penataan fisik yang paling mendukung aktifitas tersebut. Sebagaimana yang diungkapkan oleh Rusman (2011), pengaturan ruang (setting) tempet duduk peserta didik yang di lakukan bergantian, tujuannnya adalah memberikan kesempetan belajar secara merata kepada peserta didik. Pelaksanaan pembelajaran merupakan implementasi dari rencana pelaksanaan pembelajaran. Idealnya, pelaksanaan proses pembelajaran terdiri dari tiga kegiatan utama yakni kegiatan pendahuluan, kegiatan inti, dan kegiatan penutup. Pelaksanaan proses pembelajaran yang dilakukan guru sudah memenuhi ketiga kegiatan utama tersebut, namun masih banyak kegiatan yang belum terlaksana secara optimal.

Penilaian hasil pembelajaran bertujuan untuk mengukur tingkat pencapaian kompetensi peserta didik dan digunakan sebagai bahan penyusunan laporan kemajuan hasil belajar, dan memperbaiki proses pembelajaran. Melalui proses penilaian, akan diperoleh potret kemampuan peserta didik dalam mencapai standar kompetensi dan kompetensi dasar.

Berdasarkan hasil telah dokumen RPP mata pelajaran matematika, penilaian dalam RPP mata pelajaran matematika dibuat perkompetensi dasar. Penilaian yang dicantumkan merupakan contoh penilaian yang akan digunakan pada akhir pembelajaran. Soal yang digunakan dalam penilaian, merupakan soal yang akan menunjukkan pencapaian dan pemahaman peserta didik terhadap indikator pencapai kompetensi.

Penilaian hasil pembelajaran matematika yang dilakukan guru tidak menggunakan Standar Penilaian dan Panduan Penilaian Kelompok Mata Pelajaran. Pengembangan rancangan penilaian hasil belajar matematika, disesuaikan dengan tiap indikator pencapai kompetensi, materi yang sudah diajarkan dan kemampuan peserta didik. Pengawasan terhadap proses pembelajaran matematika sudah dilaksanakan dengan baik oleh kepala sekolah.

Sagala (2012) menyatakan guru dituntut untuk mampu dan dapat mengatur waktu dan kegiatan yang fleksibel, sehingga ketiga rangkaian kegiatan tersebut diterima oleh peserta didik secara utuh. Ketidaksesuain standar proses dengan proses pembelajaran matematika yang riil terjadi mempengaruhi mutu pembelajaran matematika. Dampak dari itu semua pembelajaran yang terjadi menjadi tidak maksimal.

Pembelajaran merupakan kegiatan yang dirancang guru agar peserta didik melakukan kegiatan pembelajaran untuk mencapai tujuan atau kompetensi yang diharapkan. Komalasari (2011) menyatakan proses pembelajaran dipengaruhi oleh faktor lingkungan dan faktor instrumental. Faktor lingkungan dapat berupa alam dan sosial budaya, sedangkan instrumental dapat berupa kurikulum, program, sumber daya guru, san fasilitas pendidikan. 
Oleh karena itu faktor pendukung, maupun faktor penghambat menjadi kunci dalam implementasi standar proses dalam pembelajaran matematika.

\section{SIMPULAN DAN SARAN}

Proses pembelajaran matematika yang dilaksanakan mengikuti alur standar proses ideal. Implementasi standar proses dalam pembelajaran matematika meliputi perencanaan proses pembelajaran matematika, pelaksanaan proses pembelajaran matematika, penilaian hasil pembelajaran matematika, dan pengawasan proses pembelajaran matematika. Hasil analisis CSE-UCLA terhadap proses pembelajaran matematika secara umum menyimpulkan bahwa sekolah pada dasarnya telah mengembangkan proses pembelajaran matematika di setiap tahapananya berdasarkan standar proses ideal. Dampak-dampak yang terjadi dalam proses pembelajaran, yaitu proses pembelajaran matematika tidak maksimal, dan sekolah terhambat menghadapi pembaharuan termasuk peningkatan mutu proses pembelajaran matematika.

Implementasi standar proses pada pembelajaran matematika di SMP berimplikasi pada serangkaian proses pembelajaran matematika akan saling berinteraksi secara positif, dan diarahkan untuk mewujudkan proses pembelajaran yang berdaya tarik, efektif dan efisien. Selain itu melalui penerapan standar proses pada pembelajaran matematika akan dapat meningkatkan hasil belajar matematika peserta didik. Adapun saran yang dapat diberikan adalah guru matematika hendaknya mengembangkan sendiri indikator pencapaian sesuai tingkat kemampuan peserta didik agar penilaian yang dilakukan benarbenar mengukur kemampuan kompetensi peserta didik, guru sebagai pengembang pembelajaran matematika harus memiliki pengetahuan dan keterampilan yang memadai dalam mengembangkan proses pembelajaran matematika yang sesuai dengan standar proses ideal. Guru menanggung resiko ketika berdiri dihadapan para peserta didik dan melaksanakan pembelajaran. Setiap masalah yang ditemukan dalam pembelajaran merupakan embrio tumbuhnya kreativitas baru untuk memperbaiki kondisi kedepan (Syaifurahman, 2013: 35). Faktor penghambat yang ditemukan merupakan tantangan bagi guru maupun sekolah untuk mengimplementasikan standar proses lebih baik dalam proses pembelajaran. Selain itu harus memperhatikan faktor pendukung dan faktor penghambat implementasi standar proses.

\section{DAFTAR PUSTAKA}

Adu, N., \& Boaduo, P. (2011). "Systematic Analysis and Interpretation of Collected Data For A Research Study: A Practical Methodological Framework For Writing Research Report". Educational Research and Review Vol 6. No 2, 140-146.

Akinoglu, O. (2008). "Primary Education Curriculum Reform in Turkey". World Applied Science Journal Vol 3 No 2, 195-199.

Alkin, M, C. (1969). Evaluation Theory Development. Loc Angeles: UCLA CSE Evaluation Comment.

Anthony, G., \& Margaret, W. (2009). "Characteristics of Effective Teaching of Mathematics: A View from the West". Journal of Mathematics Education, Vol. 2 No. 2, 147-164. 
Arikunto, S., \& Cepi, S. (2010). Evaluasi Program Pendidikan Pedoman Teoritis Praktis Bagi Mahasiswa dan Praktisi Pendidikan Edisi Kedua. Jakarta : Bumi Aksara

Badan Standar Nasional Pendidikan. (2006). Panduan Penyusunan Kurikulum Tingkat satuan Pendidikan Jenjang Pendidikan Dasar dan Menengah. Jakarta: BSNP

Badan Standar Nasional Pendidikan. (2006). Standar Isi untuk Satuan Pendidikan Dasar dan Menengah Standar Kompetensi dan Kompetensi Dasar SMP/MTs. Jakarta: BSNP.

Badan Standar Nasional Pendidikan. (2007). Permendiknas RI Nomor 41 tahun 2007 Tentang Standar Proses untuk Satuan Pendidikan Dasar dan Menengah. Jakarta: BSNP.

Bharvad, A. J. (2010). "Curriculum Evaluation". International Research Journal, Vol 1 Issue $12,72-74$.

Bulut, M. (2007). "Curriculum Reform In Turkey A Case Of Primary School Mathematics Curriculum". Eurasia journal of mathematics science \& technology education, Vol 3 No 3, 203-212.

Chapman, O. (2010). "Teachers' Self-Representation in Teaching Mathematics". J Math Teacher Educ. No.13, 289-294

Chapman, O. (2012). "Challenges in Mathematics Teacher Education". J Math Teacher Educ , No.15, 263-270.

Hamzah. (2009). Perencanaan Pembelajaran. Jakarta: Bumi Aksara

Hilario, R. R., \& Wei, D. (2006). Elementary Mathematics Education Curriculum of Japan and the Philippines. Jepang : CiNii, National Institute of Informatics Scholarly and Academic Information Navigator.

Hudojo, H. (1988). Mengajar Belajar Matematika. Jakarta: Depdikbud

Hudojo, H. (2003). Pengembangan Kurikulum dan Pembelajaran matematika. Malang: JICA.

Majid, A. (2008). Perencanaan Pembelajaran Mengembangkan Standar Kompetensi Guru. Bandung: ROSDA

Mulyasa. (2010). Implementasi Kurikulum Tingkat Satuan Pendidikan Kemandirian Guru dan Kepala Sekolah. Jakarta: Bumi Aksara.

Musclich, M. (2009). KTSP Pembelajaran Berbasis Kompetensi dan Kontekstual. Jakarta: Bumi Aksara

Nyre, G. F., \& Rose, C. (1979). "CSE, MO, and AA: Three Evaluatio Strategies". POD Quarterly. The Journal of The Professional and Organizational Development Network in Higher Education, Vol.1 No.4, 245-249.

Rusman. (2011). Model-Model Pembelajaran: Mengembangkan Profisionalisme Guru. Jakarta: Rajawali Pers.

Sagala, S. (2012). Konsep dan Makna Pembelajaran untuk Membantu Memecahkan Problematika Belajar dan Mengajar. Bandung: ALFABETA

Tim PISA Indonesia. (2011). Survei Internasianal PISA. Diakses pada tanggal 15 November 2012 melalui situs: http://litbang.kemdikbud.go.id/detail.php?id=215 